\title{
A Synthesis of Studies on Land Use and Land Cover Dynamics during 1930-2015 in Bangladesh
}

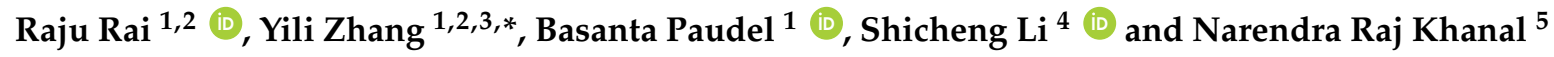 \\ 1 Key Laboratory of Land Surface Pattern and Simulation, Institute of Geographic Sciences and Natural \\ Resources Research, Chinese Academy of Sciences, Beijing 100101, China; rairaju@igsnrr.ac.cn (R.R.); \\ paudelb@igsnrr.ac.cn (B.P.) \\ 2 University of Chinese Academy of Sciences, Beijing 100049, China \\ 3 CAS Centre for Excellence in Tibetan Plateau Earth Sciences, Beijing 100101, China \\ 4 School of Public Administration, China University of Geosciences, Wuhan 430074, China; \\ lisc.10s@igsnrr.ac.cn \\ 5 Central Department of Geography, Tribhuvan University, Kirtipur, Kathmandu 44613, Nepal; \\ nrkhanal.geog@gmail.com \\ * Correspondence: zhangyl@igsnrr.ac.cn
}

Received: 25 August 2017; Accepted: 14 October 2017; Published: 24 October 2017

\begin{abstract}
Land use and land cover (LULC) is dynamic and changes in it have important environmental and socio-economic consequences. The pathways and pace of change vary with space and time and are related to the interaction between human activities and biophysical conditions in an area. This study provides a systematic review of the changing status, patterns, and compositions of LULC in Bangladesh on national, regional, and local scales over the past 85 years. The primary LULC classes in Bangladesh are agricultural land, urban and built-up area, forest and vegetation, water bodies, and wetlands. Most of the country is covered with agricultural land, followed by urban areas; the latter has been expanding rapidly in the area surrounding the capital city, Dhaka, especially the southern capital area. Forest cover is mostly concentrated in southeast Bangladesh, the Chittagong district, and the mangrove forests are predominantly located in the southwest, with the Gangetic delta. High population growth, rapid urbanization, and infrastructure development have been directly associated with changing patterns of land use across the country. In recent decades, urban areas and water bodies have been increasing, to the detriment of both forests and agricultural land. Most of the studies reviewed here describe a general trend involving agricultural and forested land being transformed into urban areas.
\end{abstract}

Keywords: land use; land cover; systematic review; Bangladesh

\section{Introduction}

Land cover is the physical cover observed on the Earth's surface, and land use describes its function [1]; both are fundamental components of global environmental change with direct implications for the Earth's climate, ecology, and human society [2]. Anthropogenic activities have been the dominant force shaping land use in recent years [3], although, their impacts vary spatially and temporally [4]. In recent decades, global land use change has been characterized by urban area growth and expanding agricultural land [5]. Rapidly increasing population growth has resulted in high rates of deforestation and large tracts of forests transitioning into cultivated land; this transition has been recognized as a dominant land cover worldwide [6]. Asia has undergone the most rapid land cover changes in recent years; which has resulted in rapidly increasing cropland and large-scale deforestation in south Asian countries [7]. The major documented issues associated with land use and land cover change (LUCC) are forest cover change, logging, fires, drainage or other forms of alteration of wetlands, 
soil degradation in croplands, and changes in the extent and productive capacity of pastoral lands [8]. Between 1990-2000 and 2000-2005, forest transformations to other land uses have increased from 3 to 6 million ha per year in Asia [9].

The area of per capita arable land in the south Asia is very low as compared to other continents. According to Food and Agriculture Organization (FAO) (2014), after the Maldives in south Asia, the $0.06 \mathrm{ha}$ / person for Bangladesh is the lowest per capita land ratio worldwide. The area of arable land available per capita in south Asia is less than 0.4 ha/person. Clearly, the per capita agricultural land is decreasing as total population continues to increase. Among south Asian countries, Bangladesh potentially has the most serious conditions per capita agriculture land, with the rate decreasing 0.11 , 0.09, 0.07, and $0.06 \mathrm{ha}$ / person in 1981, 1991, 2001, and 2011, respectively (Figure 4e) [10,11]. In addition, due to the high population growth, per capita arable land was about 2122 person $/ \mathrm{km}^{2}$ in 2016 [12], which is the least area per person within the Asian countries outside of the Maldives. Therefore, it also called the land-hungry country [13].

Urban expansion is expected to increase $1.8-2.4 \%$ by 2030 at the cost of global cropland and $80 \%$ of global cropland loss from urban expansion will take place in Asia and Africa [14]. Bangladesh was currently ranked 4th in urban growth within the Asian countries for 2000-2011 with a rate of 4.8\% 2000-2011 [11]. The rapidly increasing population and declining rate of agricultural land/per capita is becoming a major concern for food security in Bangladesh, every year the country imports millions of metric tons of food from neighboring countries.

Scientifically and systematically documenting LUCC over past several decades is important for understanding the consequences of these changes for human welfare [7]. Therefore, the objective of this paper is to provide a systematic documentation of LUCC in Bangladesh at different spatial and temporal scales covering from 1930 to 2015. For this study, we collected and reviewed published literature from various sources and extracted data from different time periods at national and sub-national spatial scales.

\section{Study Area and Source of Data}

\subsection{Study Area}

This study incorporated data for the entire country of Bangladesh, between the latitudes $20^{\circ} 34^{\prime}-26^{\circ} 38^{\prime} \mathrm{N}$ and longitudes $88^{\circ} 51^{\prime}-92^{\circ} 41^{\prime} \mathrm{E}$, with an area of $147,570 \mathrm{~km}^{2}$ [15]. It shares land borders with India to the west, north, and northeast, Myanmar to the southeast, and the Bay of Bengal to the south (Figure 1). Administratively, the country is divided into major 8 divisions, 64 districts, and 534 sub-districts (Thana), 11 city corporations, 323 municipalities, 4553 union councils and Pauroshava. Before attaining independence, the country was governed by Pakistan as East Pakistan from 1947 to 1971. The country became a sovereign state in December 1971 [16]. The national territory is situated on one of the largest and most complex deltas in the world, where the Ganges-Brahmaputra and Meghna (GBM) rivers enter the Bay of Bengal [17]. The GBM trans-boundary river basin flows through the central part of the country (Figure 1). The mega-river basin has played a crucial role in supporting agriculture, groundwater recharge, fish farming, and land building activities throughout history [18]. Almost landmass of the country lies on the lower Ganges plain, with productive alluvial soil. 


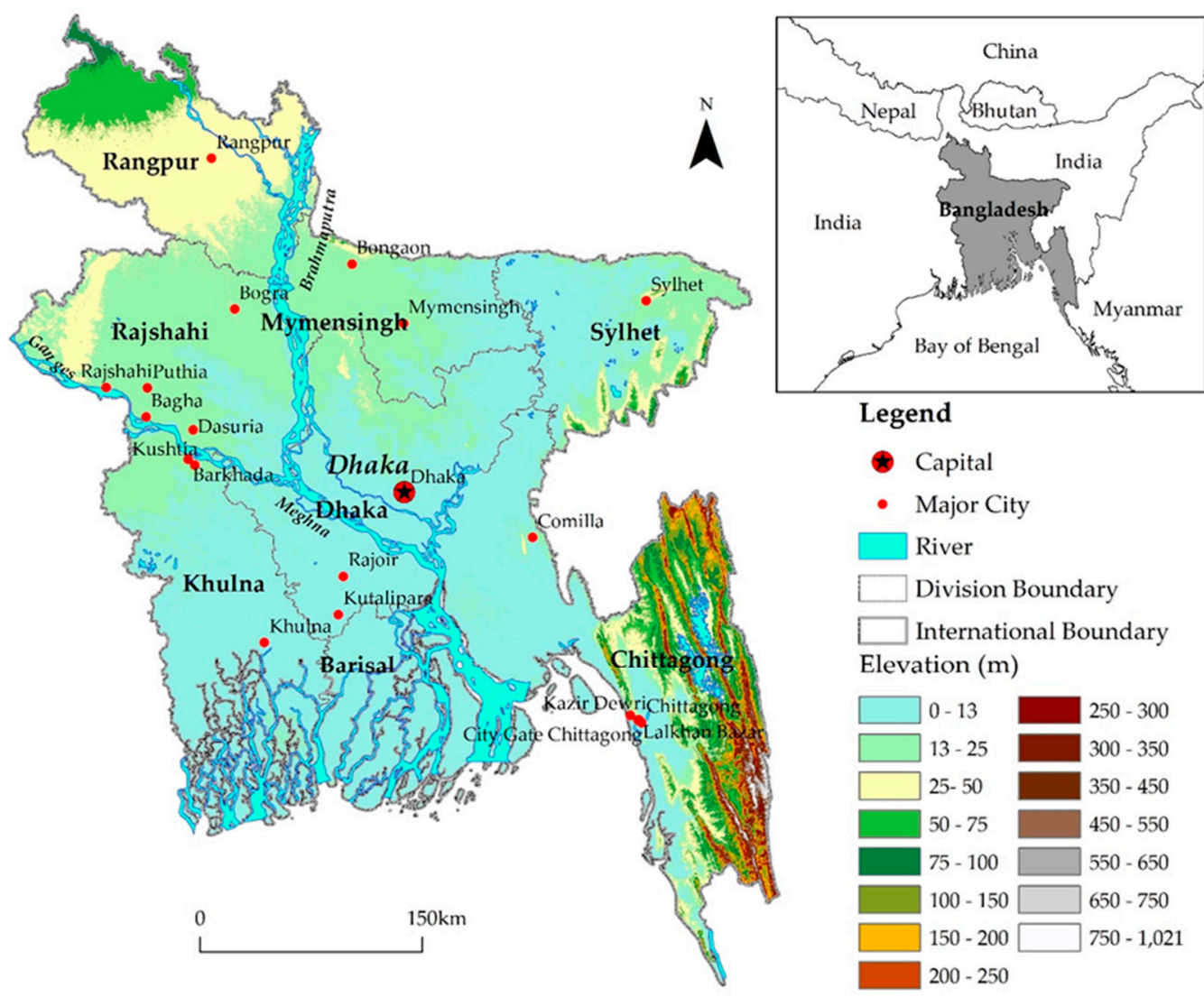

Figure 1. Location of Bangladesh with altitudinal and administrative division noted (Data source: http:/ / www.naturalearthdata.com).

\subsection{Source of Data}

To provide a systematic review of the overall status and changing LULC scenarios over 85 years in Bangladesh, we reviewed available published literature and LULC documents. The present study reviewed various literatures, documents, reports and also used spatial datasets. The available national level LUCC study has listed in Table 1. Specific methods and techniques have been followed and applied to synthesize overall LULC documents and information therein (Figure 2).

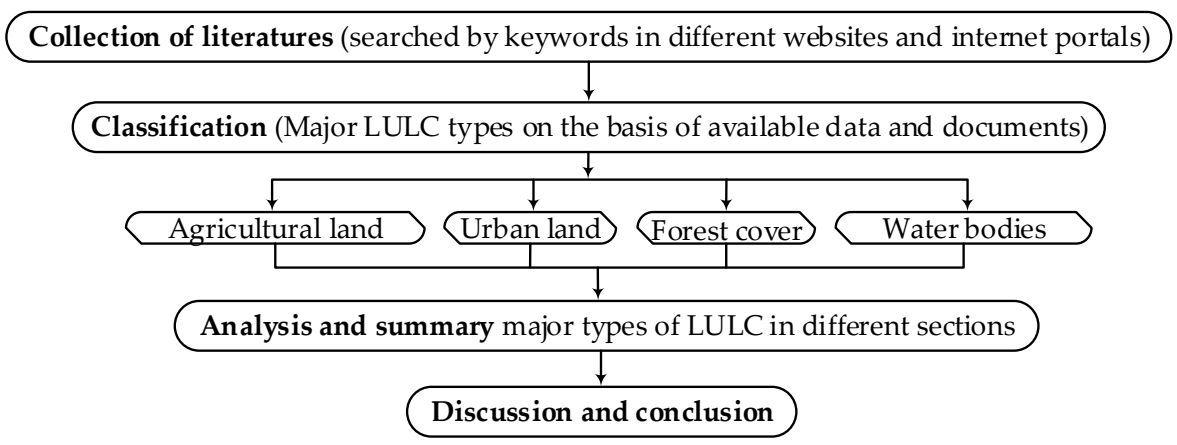

Figure 2. Flowchart of the method used in this study associated for collection, processing and synthesize the literatures on LULC dynamics.

First, the study collected available literature from the various internet resources, such as Google Scholar, web of science (WOS), Google search, ResearchGate, and specific journals sites-Elsevier, 
Springer, Science, Nature, and others. Further, LULC datasets for Bangladesh, we were obtained from other internet portals such as the Food and Agriculture Organization (FAO), Bangladesh Bureau of Statistics (BBS), Bangladesh Agricultural Research Council (BARC), and Bangladesh agricultural statistics, pockets books and so on. The literature was searched with keywords, such as land use land cover, land use land cover change, land use land cover dynamics, agriculture land, cropland, forest cover and/mangrove forests, urban land, and Bangladesh.

Second, these literature resources were categorized into major land classes, such as agriculture land (including cropland), urban land, forest (including mangrove forest), and water bodies. Third, the literature, documents, and reports were summarized on the basis of LULC types. Finally, LUCC scenarios at the national and sub-national scales, division, district, sub-district, city, municipality, and ward, were analyzed on the basis of available literature, datasets, and documents.

Studies on LUCC in the past used aerial photographs, topographic maps, satellite imageries with ground truthing to generate primary data. The different sources of data, temporal coverage, and methods adopted in various studies have listed in Table 1 . The spatial studies were carried out by collecting the data from different internet sources such as topographical maps prepared by Army Map Service, U.S. Army, Washington (http:/ / www.lib.utexas.edu/maps/ams/india), satellite images by USGS earth explorer (https: / / earthexplorer.usgs.gov), Google Earth (http:/ / earth.google.com). Most of the studies had used the series of Landsat images. The qualitative studies on LUCC were done by using the secondary sources from different official statistical books, reports, research papers as well national and international project reports. Mostly, non-spatial studies were carried out by using the data of BBS, BARC, FAO, statistical yearbooks and published literature and so on.

\section{Composition, Distribution and Change of Major LULC Classes}

The LUCC results were mainly synthesized into two categories: (1) at the national level; and (2) at the sub-national level, including division, district, sub-district, city corporation, and municipalities, ward. Results were analyzed in the context of agriculture, urban, forest, and water bodies including wetlands and shrimp farming.

\subsection{Overall LUCC Scenario at the National Level}

Bangladesh is a predominantly agrarian country due to its fertile soil and favorable weather, which is suitable for many varieties of crops in a year [19]. Currently, around $60 \%$ of the land in Bangladesh is available for cultivation. However, agricultural land has been lost due to rapid urbanization, industrialization and soil salinization [20]. Suitability index mapping found that most areas across the country have potential for agricultural activities, except the southeastern, southwestern, and northeastern margins of the country. Moreover, 353 out of 485 sub-districts have suitable growing condition for at least one cereal crop in at least two seasons per year [21].

However, LUCC research results suggest that in the 1990s, agricultural land, forest cover, mangrove forests, and water bodies have decreased in area, concurrent with the significant increases in urbanization throughout the country [17]. Agricultural land area losses have been due to transformations to built-up areas [22].

National, spatial and non-spatial historical studies have pointed out the decreasing trend in agricultural land, in comparison to the increasing area of urban land in Bangladesh. The total area of agricultural land including cropland, forest, mangrove, river, lake, beel and haor, aquaculture, tea estates and saltpans has decreased 1.12 million ha, while non-agricultural land increased 1.22 million ha between 1976 and 2010 (Figure 3) [10].

Key changes:

> Spatio-temporal studies revealed that in 1976, the total area of agriculture land was $67.38 \%$ of the country [10] but, due to high population growth and land demands, the agricultural land contraction rate was $0.13-1 \%$ per year during 1976-2010 [10,22]. In 2014, the agricultural land has revealed $62.2 \%$ [23] (Figure $4 b$ ). 
$>$ The person to land ratio is very low, $0.06 \mathrm{ha}$ /person in 2011 (Figure 4e) [10,11]. Therefore, it is clear that agricultural land is decreasing due to increasing total population and urbanization.

$>$ The pattern of the agricultural land contraction has resulted in farmers adopting intensive and diverse agricultural practices with high-yield crop varieties. The cropping intensity has increased by $4 \%$ between 1948 to 2006 [24]. Cropland areas expanded at a rate of $0.28 \%$ per annum for 1980-2000 [25].

$>$ Overall, the urban areas of the country increased significantly between 1976 and 2014 (Figure 4c). In 1976, the urban and industrial areas were listed as 26,799 ha, which increased to 47,495 ha in 2000, 87,616 ha in 2010 [10], and 1,644,300 ha in 2014 [23]. Among the various urban areas, the highest urban growth has found in Dhaka from 11 to 344\% between 1960 to 2005 [26].

$>$ The historical study on forest cover has examined that the area has been in decreasing trend. In 1930, the total forest cover was $15.7 \%$ of the total area, but the area has observed by $9.5 \%$ in 2014 . A net loss has found $6.2 \%\left(9054 \mathrm{~km}^{2}\right)$ over the past 85 years [23].

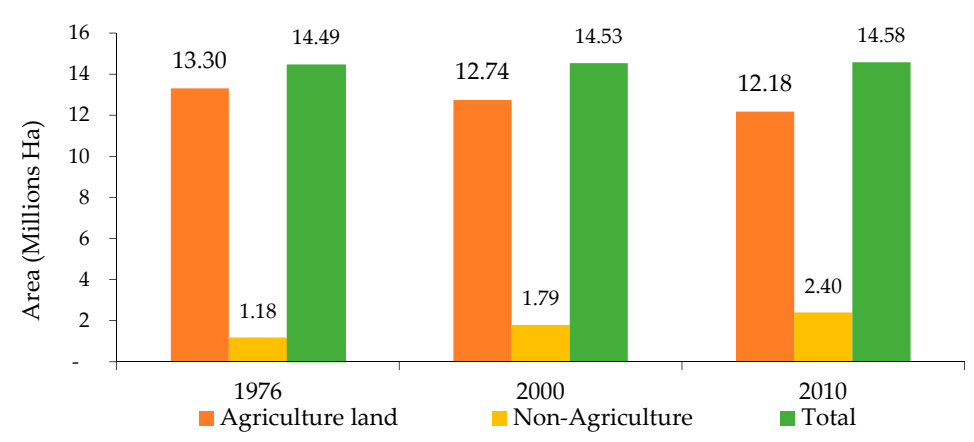

Figure 3. Agricultural land and non-agricultural land use change in Bangladesh between 1976 and $2010[10]$.

Historical studies of forest cover change and deforestation have been carried out since 1930 at the national level using topographic maps. Spatial analysis has shown that the total forest cover is declining in area and quality. U.S. topographic maps and recent high-resolution satellite image-based analysis have indicated that forest cover declined from 15.7 to $9.5 \%$ from 1930 to 2014 (Figure 4a). Forest change has been primarily to shrubland for agricultural and plantation use [23]. Additionally, shifting cultivation has also driven forest cover degradation, as documented from 1985/86 to 1992/93. Satellite image-based analysis indicated that healthy evergreen forest was significantly converted to degraded evergreen forest and some areas were converted into agricultural land [17]. FAO (2000) study also pointed out the decreasing forest cover trend between 1970 to 1990, reporting 15\%, 14\%, and $13 \%$ forest cover area during the 1970s, 1980s, and 1990s, respectively. However, there are noticeable inconsistencies between the FAO study and various national level studies regarding forest change. Satellite imagery analysis has shown that the total area of mangrove forest has not significantly changed in total area compared to other forest covers (Figure 4d) [10,27].

In Bangladesh, the sources of water are primarily surface and ground waters such as rivers and khals, lakes, beel, haor, char, and wetlands. Beel refers to lowlands mainly lying in the floodplains and deltaic region. Haor refers to the low-lying vast depression areas that flood during the monsoon and dries out in winter $[28,29]$. The haor areas are mostly located in the north-eastern part of the country that plays significant roles in the livelihoods of surrounding communities as well maintenance of biodiversity [30]. The total areas of beel and haor have slightly increased. On the basis of satellite image analysis, the total area increased from 1.66 to $1.72 \%$, about $0.002 \%$ annually from 1976 to 2010 [10].

The country has around $40 \%$ of land below 13 m elevation (Figure 1). Therefore, during monsoon season; rainfall, flooding, and surges have converted agricultural land to water bodies in the various lowlands across the country. From 1977 to 2000, the total water body area increased by 7800.49 ha 
(Figure 4f) [31]. As a result, aquaculture area increased from $0.004 \%$ to $1.21 \%$ between 1976 and 2010 [10]. The grasslands are primarily situated north of Dhaka. However, the area has decreased considerably, from 5595 ha to 1115 ha, between 1977 and 2000. Concurrently, the total area of shrubland increased 1582 ha [31]. Due to having the large coastal area, the country gained 90,512 ha of accreted land between 1976 to 2010 in the coastal region [10].
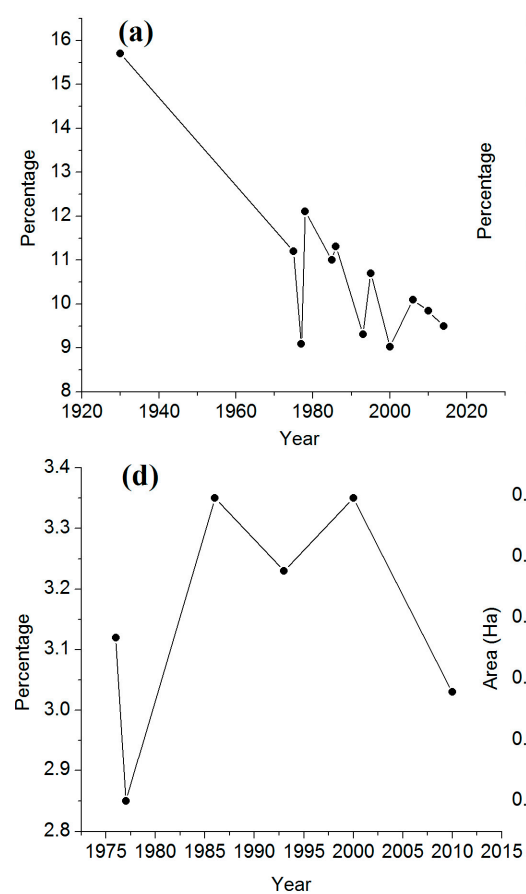

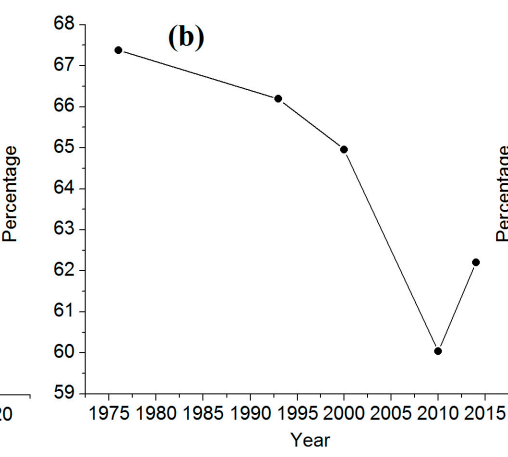

(e)

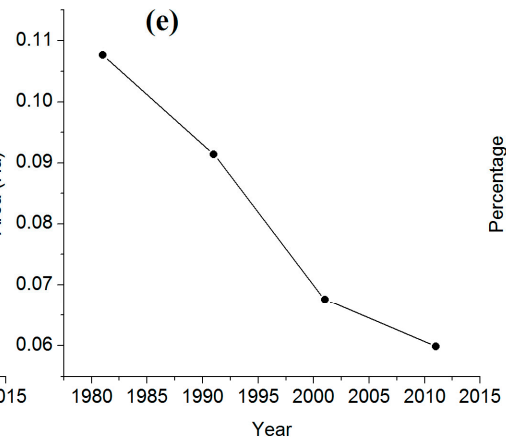

(c)
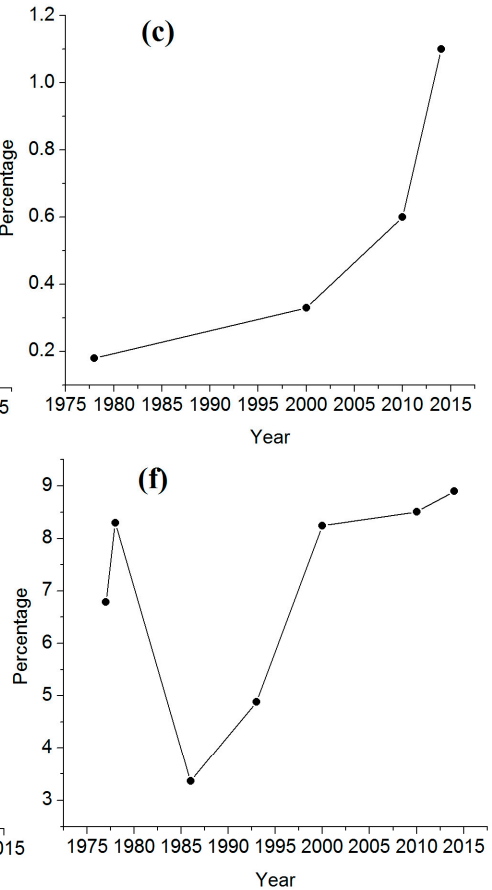

Figure 4. The different LUCC status at the national level from 1930 to 2014; (a) Forest cover, (b) Agricultural land, (c) Built-up area, (d) Mangrove forest, (e) Agricultural land per person and (f) Water bodies; Sources for different time periods: 1977 [31], 1976, 2000, 2010 [10], 1986, 1993 [17], Agricultural land per person [10,11] and forest cover 1930-2014 [23].

Table 1. Overview of LUCC studies at the national scale.

\begin{tabular}{ccccc}
\hline Research Theme & Data Sources & Temporal Coverage & Methodology & Source \\
\hline Agricultural land use & Field survey & $1950-1986$ & Time series analysis & {$[32]$} \\
\hline Land cover mapping & NOAA/AVHRR & $1985 / 86-1992 / 93$ & ERDAS \& Arc-Info & {$[17]$} \\
\hline Land use change & BBS & $1980-2000$ & Quantitative analysis & {$[25]$} \\
\hline Land cover change & Landsat images & $1977-2001$ & $\begin{array}{c}\text { Knowledge-based } \\
\text { classification }\end{array}$ & {$[31]$} \\
\hline Agricultural land use & Agricultural statistics & $1948-2006$ & Time series analysis & {$[24]$} \\
\hline $\begin{array}{c}\text { Agricultural land } \\
\text { conservation }\end{array}$ & Field survey & $2001-2008$ & Quantitative analysis & {$[22]$} \\
\hline Agricultural land use & Landsat images & $1976-2010$ & Hybrid interpretation & {$[10]$} \\
\hline $\begin{array}{c}\text { Mapping of } \\
\text { agricultural potential }\end{array}$ & BBS, BARC & 2013 & Suitability index & {$[21]$} \\
\hline $\begin{array}{c}\text { Deforestation } \\
\text { Topographic maps, } \\
\text { IRS P6 AWiFs }\end{array}$ & $1930-2014$ & $\begin{array}{c}\text { Time series analysis, } \\
\text { Gi* statistic }\end{array}$ & {$[23]$} \\
\hline
\end{tabular}




\subsection{LUCC at the Sub-National Level}

\subsubsection{Agricultural Land}

Since historical time period, the agricultural land has transforming to non-agricultural land use at different spatio-temporal scales. Clearly, previous research has shown that agricultural land has been primarily transformed into urban land in recent decades $[10,22,33,34]$. Annually agricultural land was converted to non-agricultural land in different rate within the country. Among the divisions, the conversion rates were the highest for the Dhaka division at $1.45 \%$, other conversion rates included Khulna at $0.26 \%$ (2001-2008) [22], Chittagong at 1.32\%, Barisal at $0.08 \%$ (2000-2010) [10], Fulbaria at $0.54 \%$ and Trisal Upazila (sub-district) at $0.62 \%$ for $1983-2000$ [35].

Due to increasing urban areas, agricultural land has decreased at various places in Dhaka division and proximity areas [10,36-38]. Griffiths et al. (2010) also showed that agricultural land decreased to 73.7\% between 1990 and 2006 in Dhaka city. Overall, agricultural land decreased 39.94\% between 1960 and 2014 in Dhaka city [33]. On the basis of existing spatial studies, the Markov chain model based analysis estimated that the agricultural land conversion to built-up by $26 \%$ between 2008 and 2020 in the city [39].

Agricultural land in western division Rajshahi and Rangpur have been continuously contracting, primarily placed with urban development. As a result, the annual agricultural land transformation has resulted in declining food production and higher food costs in recent periods [40]. However, regarding Bogra district, abandoned agricultural land transformed to cropland by 5\% between 1988-2004 [41]. On average, cropland decreased $0.52 \%$ annually in Rajshahi and $0.17 \%$ in Rangpur division between 1976 and 2010 [10]. However, the rate of change has been higher in small areas where declined by 3 to $7 \%$ in small scales such city corporation, and sub-district [42,43]. Overall, the cropland change in two adjoining divisions (Rajshahi and Rangpur) were higher than in other divisions in the three time periods 1976, 2000, and 2010 (Figure 5).

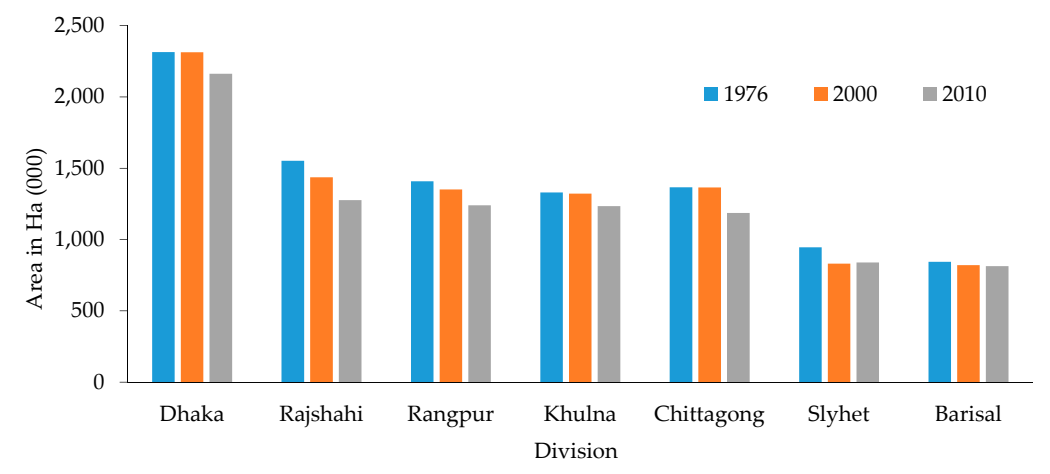

Figure 5. Changing cropland status between 1976-2010 in different division of Bangladesh [10].

Over the past 34 years, the cropland area in the adjoining eastern divisions (Chittagong and Sylhet) have decreased annually at a rate of $0.39 \%$ and $0.33 \%$, respectively [10]. However, due to population growth and pressure on land as well shifting cultivation, the cropland area increased by $11 \%$ and $56 \%$ at the small areas of Chittagong and Sylhet division, respectively [44-46].

Since times past, rice fields are the most dominant land in the rural villages of coastal districts. However, due to high profits from shrimp and salt farming, the rice fields are changing to another use [47-50]. Shrimp farming has affected around 1 million ha of arable land in the southern coastal area [51]. As a result, the total water body area increased 10\% (Khulna, Satkhira, and Sundarban) between 1980 and 2009 [52]. Between 1989 and 2010, shrimp farming increased significantly, at the rate of $2.05 \%$ annually, in the Ganges Tidal floodplain which altered $31 \%$ of rice land to shrimp and salt farming during 1978 to 2009 [53,54]. Similarly, salt farming increased significantly from $2 \%$ to $23 \%$ between 1974 and 2012, while the agricultural land declined from $36 \%$ to $7 \%$ in the Chakaria 
Sundarbans mangrove forest area [55]. Likewise, in Barisal division, more than $66 \%$ land was covered with cropland between 1976 and 2010. However, cropland has declined $0.10 \%$ annually [10].

Increasing population has naturally forced farmers to adopt intensive agriculture that use advanced methods and new technology [48]. For example, after incorporating hybrid seeds with different varieties of rice for cultivation in Gazipur district, the paddy area increased 7\% during 2000 to 2009 [56]. Natural disasters have also facilitated LUCC. For instance, due to waterlogging problems in the Hari-Teka river basin of the Jessore district, the settlement was converted to the agricultural land, which subsequently increased in area $4.73 \%$ from 2000 to 2004 [57].

\subsubsection{Urban Land}

Based on a comprehensive review of previous LULC studies, rapid population growth has resulted in high urbanization across Bangladesh. The capital city, Dhaka, and other urban centers, such as Chittagong, Sylhet, and Rajshahi have expanded rapidly. Due to political, administrative, and economic hub, the urbanization process in Dhaka has been achieving significantly since historical time. According to FAO (2014), the urban area of Bangladesh increased from $23.6 \%$ to $28.4 \%$ between 2000 and 2011. Annually, urban area increased $0.01 \%$ from 1976 to 2010 [10]. Particularly, the Dhaka division increased dramatically in this period. According to BBS (2014b), there were 155, 84, 835 urban residents (46.44\%) living in the Dhaka division in 2011. The area was 10,190 ha in 1976 but with increasing population and infrastructure, it increased 22,795 ha in 2000 and 42,747 ha in 2010. Increasing built-up area and infrastructures are indicators of development; however, the rapidly growing population and unplanned urbanization process have resulted in high land demand in the country. This has resulted in high land value and has created a yield management problem $[58,59]$. In the recent years, Dhaka city and the vicinities of other big cities have shown similar changes; rapidly growing urban areas and contraction of fertile agricultural land [18,33,34].

Historical study has found that between 1960 and 2005, the built-up area increased significantly, from $11 \%$ to $344 \%$ in Dhaka city [60]. The changing rate was not similar even a same place due to study period and methodology. On the basis of existing urbanization scenarios, Markov Chain model-based study estimated the overall expansion of urban land as 46\% to 58\% between 2009-2019 in Dhaka city [61] and 26\% for 2020-2050 [39]. In comparison, the SLEUTH model estimated the increase of urban land of $20 \%$ in the metropolitan city area by 2030 [62].

Spatial analysis indicates that the built-up area expanded primarily by replacing agricultural land, water bodies and forest area in the hinterland of Dhaka city. The urban area increased up to $29 \%$ in Gazipur district and Manikaganj sub-district from 1989 to 2009 [37,38,63]. Similarly, northeast Sylhet district also had a high rate of urbanization [64]. A field survey study found that the built-up area increased from $39.11 \%$ to $58.71 \%$ between 1988 and 2007 [65].

Chittagong city, located in the southeast, is the second largest city in Bangladesh has also a high rate of population growth and urban expansion and. In this area, several studies have been conducted using satellite images over different spatio-temporal scales [45,66-68]. Among them, one study found that urban growth was faster between 2000-2010 compared to 1976-2000, which resulted in a $2.31 \%$ to $5.73 \%$ increase over the past 34 years in Chittagong division [10]. A Geographic Information System (GIS) and Remote Sensing (RS) based study indicated that $56 \%$ of land has changed due to rapid population growth and urbanization between 1977 and 2013 in Chittagong city [66]. In comparison, small areas within the city have experienced higher urbanization trend. For example, $10 \%$ urban area gained at corporation area [69] and Chittagong city- 8 by 17.17\% between 1989 and 2001 [68].

The urbanization trend has also been rapidly increasing in the western districts, which corresponds to the contraction of agricultural land in recent decades. The urban infrastructure increased from $60 \%$ to $83.2 \%$ between 1977-2010 in Rajshahi district while the agricultural land lose were found by $0.16 \%$ yearly $[70,71]$. Similarly, the urban growth also has been faster in Rangpur district, sub-district and city corporation area [43]. During the period 1989-2014, the urban area in Rangpur sub-district increased $20 \%$ [42]. 
Urban areas in the southern cities have also increased over time [72,73]. The urban area in Kushtia city increased the most, $56.71 \%$ followed by Jessore city at $23.28 \%$, and Satkhira city at $10.03 \%$ between 1989 and 2010 [74]. However, due to waterlogging and natural hazards, the settlement area has decreased in Hari-Teka river basin. The settlement area decreased from $25.46 \%$ to $16.32 \%$ between 2000 and 2004 [57]. Notably, the decreased settlement area was only observed in the Jessore district. Therefore, natural hazards control some LUCC in this region.

A European Space Agency (ESA) (2017) LULC dataset, indicates that the settlement area of the country has increased dramatically $\left(215\right.$ to $\left.1123 \mathrm{~km}^{2}\right)$ over the past 23 years. Moreover, cropland, forest, wetland, vegetation, and bare land have also been increasing. However, concurrently, the grassland and water bodies have been in decline. The other remaining LULC types have not changed significantly across the country (Figure 6).
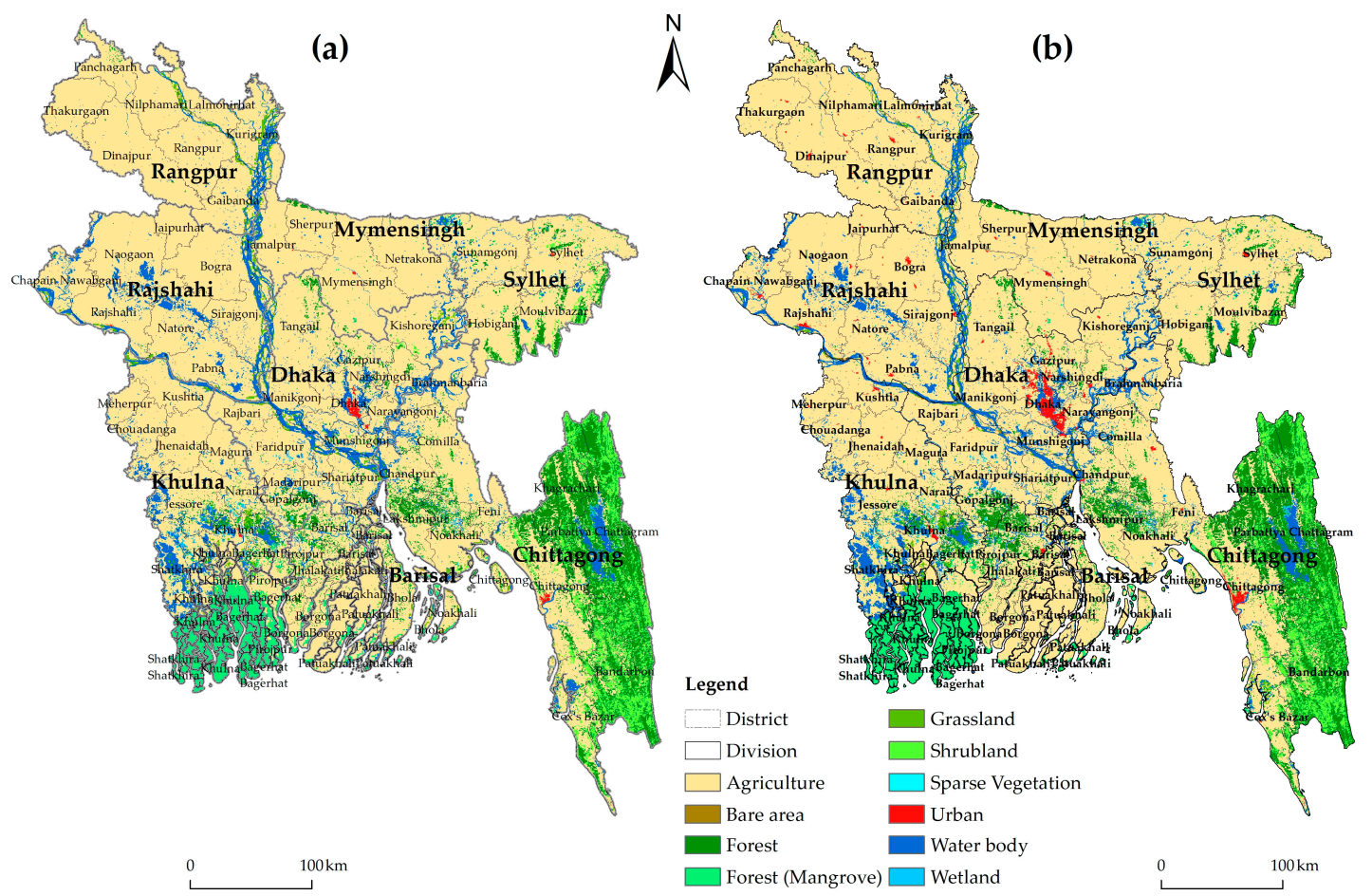

Figure 6. The spatial status and distribution of LULC in Bangladesh between 1992 (a) and 2015 (b) [75].

\subsubsection{Forest Cover}

Forest cover is mostly distributed in southern (east and west) Bangladesh (Figure 6). The largest mangrove forest, and consequently World Heritage site, is located in the southwest. On the basis of topographic setting, the forests of Bangladesh are classified as hill, sal, and mangrove forest. Over the past decades, all forest sub-groups have been decreasing. Forest cover change has primarily been observed using remotely sensed data for spatio-temporal analysis. Hasan et al. (2013) have found that total forest cover was $12.11 \%, 9.02 \%$, and $9.84 \%$ in 1976, 2000, and 2010, respectively (Figure 4a). However, FAO (2006) indicated that forest cover was not changed significantly $\left(8820\right.$ to $\left.8840 \mathrm{~km}^{2}\right)$ between 1990 and 2000. In addition, historical spatial and non-spatial studies of forest cover changes found that LUCC was driven by different factors over time. The various causes of forest decline have included; population growth, poverty, illicit felling, expansion of agricultural land and lack of appropriate policies $[63,64,76-78]$.

The increasing urban area is responsible for forest cover loss in different places. However, the decreasing rate was varied at different spatio-temporal scales. Due to the highly increasing urban area in Dhaka city and periphery, the forest, vegetation and green spaces have found lessening trend since 
historical period $[33,36,79,80]$. The green spaces including trees and gardens decreased from $35.7 \%$ to $24.1 \%$ between 1975 and 2005 in Dhaka city [81]. In overall, forest area decreased $2.32 \%$ annually between 1976 to 2010 and 3.12\% between 2000 and 2010 in Dhaka city [10].

Different models have been used to calculate the loss and prediction vegetation and forest cover. The Location Quotient method based study estimated that vegetation decreased $66 \%$ between 1960 and 2014 [33]. Similarly, the Maximum Value Composite (MVC) technique calculated a loss of $66.87 \mathrm{~km}^{2}$ area between 1989 and 2009 [82]. The Markov Chain model also estimated a vegetation to cultivation land change of 38\% for 2008-2020 in Dhaka city [39]. Due to different time periods and methodologies in different studies, the results were highly variable. However, these three models based studies revealed a generally decreasing trend in vegetation and forest cover in Dhaka city.

Gazipur district also experienced the forest cover loss since historical periods, where forest cover declined 20.29\% between 1989 and 2009 [63] and yearly forest cover lost by 2.53\% over the past 34 years in Rangpur division [10]. Forest cover in the northeast (Sylhet district) has also been lost due to urbanization. Based on a field survey analysis, forest cover was decreased from 52,930.1 to 37,031.06 ha between 1988 and 1997 [65]. However, vegetation area increased from 1714.85 to 1847.83 ha in Bhanugach reserved forest between 1996 to 2006 [83].

Forest loss has been mitigated since 2000 due to the implementation of programs and projects by the forest department. For example, in 1976 forest cover was 1,380,402 ha in the Chittagong division, and decreased to 1,116,258 ha in 2000. Then, the area has increased to 1,316,104 ha in 2010, which is nearly the 1976 area [10]. Islam and Chowdhury (2014) examined vegetation cover and found that it had decreased 55\%, 37\%, and 31\% in 1989, 2001, and 2013, respectively in Chittagong; the decreasing trend had slowed after the 2000s. Roy and Saha (2016) found that forest cover decreased from $83.36 \%$ to $55.88 \%$ in between 2002 and 2014. Furthermore, hill vegetation decreased from $18.89 \%$ to $15.93 \%$ between 1989 and 2014 in Chittagong [67]. According to the International Centre for Integrated Mountain Development (ICIMOD) (2017) dataset for LULC, hill forests decreased in area from $50.34 \%$ to $40.57 \%$ and mangrove cover slightly decreased $3.35 \%$ to $3.03 \%$ between 2000 and 2010 in greater Chittagong. However, Hasan et al. (2013) revealed that forest cover continued to decrease $1.32 \%$ in the Chittagong division during the same time span. The variability in these results for the Chittagong division are likely due to small difference in the study areas and adopted methods.

Historical spatial studies have estimated that forest cover has decreased, while shrubland has increased in Chittagong [44,45]. In overall, vegetation cover has decreased from 1989 to 2001, from 55 to $37 \%$, but the trend had slowed to $31 \%$ in 2013 in Chittagong [69]. In contrast, the participating of local people in management, the vegetation cover has improved in Haor area. Between 2000-2008, the cover increased $8.35 \%$ over the area [84]. Due to human and natural causes, the important specific vegetation types have also been declining in many parts of the country [46,85]. The Azadirachta indica species declined $95.22 \%$ in Tanguar Haor area [86]. Similarly, the Shorea robusta (sal) in the Modhupur area also decreased from 75 to $41 \%$ between 1989 and 2015 [87]. This result represents that some of the species are most likely to disappear in recent years.

The mangrove forest has a significant role in societal livelihoods and economic benefits, ecosystem services, biodiversity, climate change, and sea level rise [88-90]. Billah and Ramhan (2004) have examined the mangrove forests using satellite imagery and found that the largest area occupied by the vegetation was $48.59 \%$ in Khulna city. However, due to natural and anthropogenic causes, all vegetation cover has been declining and converted to other land categories [15,50,52,91-93]. A spatio-temporal analysis of satellite images using Normalized Difference Vegetation Index (NDVI) datasets showed that the mangrove forest decreased 15.47\% between 1989 and 2010 [94]. Overall, mangrove forest area declined $0.10 \%$ annually between 1976 and 2010 [10].

\subsubsection{Water Bodies}

Bangladesh has large sources of water resources from various channels. Many spatial and temporal studies have concluded that due to various drivers, water bodies area has decreased over 
time $[95,96]$. However, due to stagnant water during flooding, restoration activities, increasing shrimp and fish farming in the southern coastal region, water body area has increased in recent decades (Figure 4f). Based on topographic maps from 1960 and satellite images from 2008, water bodies and lowland areas decreased between 32.57\% and 52.58\% from 1960 to 2008 in Dhaka [97]. Similarly, $44.48 \%$ of water bodies and $47.32 \%$ of low/wetlands decreased between 1960 and 2014 [33]. In addition to Dhaka city, the areas surrounding big cities have shown similar decreasing patterns. Permanent wetlands decreased from $4.15 \%$ to 1.16\% between 1967 and 2010, an alarming situation in Dhaka and bordering areas [98]. Similarly, Mamun et al. (2013) found that water bodies and wetlands decreased nearly 50\% from 1990 to 2010 in Dhaka city. Overall, for 1995-2001, wetlands decreased in area 18.5\%. This declining wetlands trend has made the drainage system vulnerable in Dhaka city [99]. Therefore, Markov Chain model indicated that $11 \%$ of wetland will be converted to built-up areas between 2020 and 2050 [39].

The various causes have been driving to the decrease wetland in Dhaka and outside over the past decades [45,100]. Due to deforestation, water bodies areas declined $6.25 \%$ between 1989 and 2009 in Mirzapur, Gazipur district [63]. Haor area, Sylhet division, also decreased significantly, $14.4 \%$, due to conversions to cropland and mudflat between 1989 to 2010 [84,101]. Similarly, the area under water bodies decreased up to 3\% in Chittagong district between 1989 to 2014 [69,102]. Water body area decreased significantly in northern parts from Dhaka city [64]. The water body area decreased around 2\% in different part of Manikaganj district between 1989 and 2014 [37,38]. Such decreasing water body areas have created dry areas in some parts of the country. For example, in Hari-Teka river basin, declined water body have created $14.72 \%$ of dry land between 2000 and 2004 in the Jessore district [57].

Due to shifting of rice field to shrimp farming and saline water intrusion in the delta region, the deltaic wetlands have been under threat [103]. In the Ganges delta area, wetlands increased 500\% between 1980 and 2008 [20]. Overall, water bodies increased almost 30\% from 1999-2012 in southern Bangladesh [50]. The increasing soil salinity trends indicate threat to agricultural activities as well natural disasters. In addition, the future flooding estimated that $41.4 \%$ and $64.2 \%$ of the total polders would be inundated in 2030 and 2050, respectively. Furthermore, only $14.3 \%$ of the terrestrial land area will remain free from storm surges in coastal area by 2100 [92].

\section{Impact of LUCC and Comparison of the Historical Database}

\subsection{Impacts of LUCC Over the Country}

\subsubsection{Agricultural Land Contraction and Food Insecurity}

After independence in 1971, the increasing population resulted the widely LUCC across the country. The contraction of agricultural land to non-agricultural land resulted the various consequences over the country. The contraction rate has been slightly higher since 2000 compared to the previous decades nationally. Agricultural land has decreased up to $1.45 \%$ annually after 2000 in different divisions $[10,22]$. With the time and introduced new farming technology, the country adopted various ways to increase food production and minimize food insecurity. The start of agro-technological advancement increased the production with crop intensity, which increased per capita income more than $130 \%$ and reduced the poverty level $50 \%$. The crop production has been increasing since 1971 by the use of new technology and hybrid seeds [104,105]. During the 1980s, the improvements in agriculture as well 'green revolution' played a fundamental role in increasing of rice production, which almost doubled during the last two decades. The intensive use of chemical fertilizer has played significant role to increase food production in the country, but the scientists worried about its effects on natural environment, loss of soil organic matter, soil salinity, erosion, emission of greenhouse gases, and harms to human health $[106,107]$. However, at some villages; a diverse knowledge on local soils and the adoption of indigenous management strategies have aided in sustainable food production [108]. This strategy combined with agro-technological advancement also provided a mechanism for fulfilling 
food demand in the Damarpota and Satkhira districts in southwestern Bangladesh [109]. Due to food shortages and high profit from shrimp, the farmers replaced the rice field to shrimp farming in southern Bangladesh. After 1980s, the start of agro-shrimp farming, decreased food shortage as well the livelihood and economic status also improved at small villages [110,111].

In recent decades, the country has achieved substantial progress in enhancing food security; it has increased food production for socio-economic development [112-114]. However, still, one-third of the population remains living under the poverty line, especially in rural areas [115]. The natural disaster also the causing factor for food security in the country. Due to natural drought in northern Bangladesh especially the Rangpur and Rajshahi divisions, there are severe food scarcities, primarily rice in recent decades [104]. Still, poverty-related food insecurity is widely prevalent more than $40 \%$ (56 million) of the population lived in 'absolute poverty' and failed to acquire the minimum level of food energy per day to maintain their health as of 2005 [116]. However, overall, the gross production of rice and wheat increased significantly during the period between 1971/72 and 2010/11 from 10.46 to 35.3 million metric tons. The country requires of 23.64 million of metric tons (MMT) rice and wheat for the total population [114].

It is very clear that the food insecurity is directly related to income level of household [117], because of lower economic status, most of the fisherman prefer single family at the village of Meghna riverside [118]. Still, $40 \%$ of the rural population live with a landless status [16]. Furthermore, around $60 \%$ of farmers are functionally landless with about $62 \%$ of farming households having less than 0.4 ha of farmland [107]. Therefore, food production is not enough for all household. According to Keshem and Faroque (2011), the private and public sectors annually imported MMTs of rice and wheat. In 2001/02, the private and public sectors imported 1.29 and 0.51 MMT of rice and wheat, respectively, and in 2010/11, the amount increased to 2.08, and 1.05 MMT, respectively. Due to decline in agriculture land, the overall production declined and the problem of food insecurity is becoming more intense and they have to import food from neighboring countries.

\subsubsection{The Effects of Population Growth and Urban Land Development}

Rapid population growth is a component of urban growth, historically, those growth have been increasing significantly over the country. Multiple driving factors are responsible for the LUCC and urban expansion [119]. Since 1980s, the country's population has grown rapidly (87 to 144 million between 1981-2011) [120]. In the last few decades, the high rate of economic and population growth, infrastructure development, and impact of climate change have been major causes of rapid LUCC across the country [31]. The increasing rate is higher in every decades in the country, which creating highly land demands for housing and infrastructure. According to BBS (2014), approximately one-fourth of the national population lives in urban area, but the urban land has decreased $17.22 \%\left(10,711.89 \mathrm{~km}^{2}\right.$ to $\left.8867.42 \mathrm{~km}^{2}\right)$ between 2001 and 2011. Howerver, Hasan et al. (2013) found that the urban area increased from 474.95 to $876.16 \mathrm{~km}^{2}$ between $2000-2010$. The results are inconsistent, presenting opposite trends in urban land change: either decreasing $1844.47 \mathrm{~km}^{2}$ or increasing $401.21 \mathrm{~km}^{2}$. However, Reddy et al. (2016) found that settlement area had increased $1643 \mathrm{~km}^{2}$ $(1.1 \%)$ in 2014, which was in agreement with the results from [10]. Increasing urban population growth has resulted the urban expansion speedily, mostly in Dhaka city and other big cities, including Chittagong, Rajshahi, Satkhira, Manikaganj, and Sylhet districts. As result, infrastructure development with unplanned urbanization processes encroached on agricultural land, forestland, low-lying areas, and water bodies, resulting in the transformation from vegetation cover to concrete built-up areas. These types of changes are incorporated to vulnerable capital city as well other big cities from natural disasters and LUCC issues.

According to historical studies of Dhaka city, urban area has increased significantly to the detriment of other LULC classes [26,36,79,97]; and urban area increased from $11 \%$ to $344 \%$ between 1960 and 2014. In addition, the great revolution of land prices has been an important driver of urban migration, the land prices almost doubled, especially after 2005 in Dhaka district [59]. One of the 
obvious impact of urban growth at the cost of agricultural land is the increasing problem of food security. Similarly, the conservation of other land uses such as forest and water bodies have several environmental and socio-economic consequences.

\subsubsection{The Effects of Forest Cover and Water Bodies Changes}

Forest cover is mostly distributed in south-east and south-west Bangladesh (Figure 6). The mangrove is the largest single tract mangrove forest in the world provides important ecosystem services as well livelihood options. However, due to the high demand for wood and wood products, the overall forest cover status is decreasing rate which shows very less per capita forest land in the world. According to FAO (2010b), the average per capita forest land is 0.60 ha globally; however, in recent decades, Bangladesh has only reached 0.12 ha per capita forest land [121]. Furthermore, it decreased 0.016 ha in 2011 [122], the smallest value in a global compilation. The historical spatial study on forest cover change was found decreasing trend from $15.7 \%$ to $9.5 \%$ during 85 years [23]. Furthermore, Giri and Shrestha (1996) also found the total forest cover by $14 \%$ in 1989. This study also supported to decreased forest cover gradually with time. The forest department has implemented several massive programs and projects to regenerate and reforest after the devastating cyclone of 1960 . The impacts of these programs have been observed since 2000. Furthermore, illicit felling of forest cover also improved after 2000.

Due to foothills of the Himalayas and low lying riverine, the country shares 57 trans-boundary rivers including Ganges and Brahmaputra. The rivers play the important role for agriculture as the well high risk of floods and river erosion within the country. The large rivers, the Ganges, Brahmaputra, and Meghna, respectively drain approximately $1.8,0.85$, and 0.09 million $\mathrm{km}^{2}$ watersheds [123]. In recent decades, due to the high rate of population growth and urbanization process, the wetlands surrounding Dhaka city have seriously degraded. Urbanization is taking over low-lying area and wetlands, which shrank to $44.48 \%$ from $47.32 \%$ from 1960 to 2014 in Dhaka city [33]. This wetlands change and unplanned urbanization have made the drainage system in the capital city vulnerable to waterlogging problems and their consequences. Moreover, due to high profit from shrimp, water bodies have increased up to $500 \%$ after 1980s in the southern regions [20]. On the one hand the shrimp farming improved the local livelihood; but on the other hand, intensive shrimp farming has impacted coastal land use with creating saline water intrusions, which many harm wetlands and rice ecosystems as well decrease of rice production.

\subsection{Comparison of Historical Database}

At the national level, most historical LUCC studies have been based on non-spatial studies using different data sources (Table 1), and they have provided only improved explanations and information for historical LULC conditions $[19,22,24,25,32]$. However, only few studies have adopted the spatial data sources to examine the LUCC at a national scale $[10,17,23,31]$. These existing studies based on spatial and non-spatial data sources have produced dissimilar research findings even in cases where the satellite images were acquired at the same time and have an identical spatial resolution. The dissimilarity result could be due to adopted methodologies, spatial resolutions, and different administrative boundaries.

As far as the authors are aware, an official digital seamless spatial database for LULC of the whole country is currently unavailable. The historical spatial dataset of forest cover since 1930 were prepared by Reddy et al. (2016) using topographic maps with a scale of 1:250,000 and different satellite images. For 1930-1977, some studies were conducted based on spatial and non-spatial data sources. These results were not uniform and have vast differences. Moreover, the results show large uncertainties and discrepancies in the spatial-temporal status of historical LUCC. For example, agricultural land accounted for $65 \%$ of land cover in 2015 [124], but was only $62.2 \%$ in 2014 [23]. Changes in all LULC categories are consistently higher in non-spatial based studies, such as those based on BBS statistics, 
questionnaires, and field surveys rather than studies based on a spatial dataset. However, the results from most spatial dataset based studies are comparable.

The varying approaches adopted in LULC classification by different researchers create problems in comparing overall changes in LULC status. Existing studies have followed several classification methods. Uddin and Gurung (2010) classified LULC into 8 principal classes, bare land, grassland, shrubland, closed forest, open forest, mangrove forest, water bodies and agriculture, whereas Reddy et al. (2016) classified into 9 classes, forest, shrub, grassland, plantations, water bodies, mudflats, barren land, settlement, and agriculture land. The 17 FAO LULC classes were adopted by Hasan et al. (2013). The FAO provided a detailed classification scheme, which is difficult to compare with other common LULC classifications. Some national studies classified mangrove forest as wetlands, while others classified them separately [31], or included them within the forest class [23]. Our study also agrees that varying classification systems used in different studies have made it difficult to aggregate and compare their results [125].

Further, LUCC studies have adopted varying classification approaches over different time periods and data resources. Most historical studies adopted aerial photographs, topographic maps scaled at 1:250,000 for LULC studies prior to the introduction and availability of satellite technology and imagery. The existing spatial studies adopted either unsupervised, supervised, hybrid interpretation or knowledge-based classification approaches. These different methods and data sources clearly provided differing results. However, due to the innovative new technology, high-resolution satellite images are easily available at no cost, which has created a convenient environment to analyze LUCC.

Due to the large coastal area in the south, the total area of the country has increased in the last few decades. Overall, Bangladesh gained 90,512 ha land in between 1976 to 2010 [10]. Therefore, scholars have provided different total areas for the country despite the governmental having defined the total area of the county as $147,570 \mathrm{~km}^{2}$. These adopted different boundary has created difficulties in comparing the results (Table 2).

Table 2. The total area of Bangladesh in different time periods.

\begin{tabular}{ccc}
\hline Year & Area $\left.\mathbf{( k m}^{\mathbf{2}}\right)$ & Source \\
\hline 1976 & $144,837.0$ & {$[10]$} \\
1977 & $144,688.8$ & {$[31]$} \\
2000 & $145,306.0$ & {$[10]$} \\
2000 & $144,688.8$ & {$[31]$} \\
2010 & $145,778.0$ & {$[10]$} \\
2013 & $147,872.0$ & {$[126]$} \\
2014 & $147,570.0$ & {$[23]$} \\
2015 & $144,570.0$ & {$[127]$} \\
\hline
\end{tabular}

\section{Conclusions}

Bangladesh has undergone rapid LUCC due to speedy population growth and urbanization that resulted sharp contractions in agricultural land. The study covers the LULC dynamics from 1930 to 2015 over the country at different spatio-temporal scales. The agricultural land decreased from $67.38 \%$ to $62.2 \%$ between 1976 and 2014. The agricultural land was converted to non-agricultural land at an annual rate of $0.56 \%$ between 2001 and 2008. Most urbanization has been found in Dhaka city and the peripheral areas. The urban area increased the highest in Dhaka city, from 11 to 344\% between 1960 to 2005. The forest cover has been decreasing since 1930. A net forest cover loss has found $9054 \mathrm{~km}^{2}$ over the past 8 decades. However, the mangrove forest cover has not significantly changed within the overall forest categories. The overall, water bodies have slightly increased over the historical period. However, permanent wetlands have been decreasing at an alarming rate, especially in Dhaka and the neighboring areas. In Dhaka city, more than $49 \%$ of the wetland areas decreased between 1960 and 2008. In contrast, the wetlands in the Ganges delta increased 500\% between 1980 and 2008. 
Based on the systematic review of numerous studies of LULC in Bangladesh, this study concluded that the existing studies do not provide enough data at national as well sub-national scale. Furthermore, the historical spatio-temporal LUCC results are inconsistent between studies. Further LUCC study is needed to examine the historical data with new methods, tools, and data resources in the context of environmental change at the national and regional scale. The trans-boundary Ganga-Brahmaputra river basin is one of the most important water resources in South Asian countries for agriculture and human needs, yet few studies have addressed this area. Further LUCC study is needed to improve accuracy, eliminate uncertainties and discrepancies in the spatio-temporal changes.

Acknowledgments: This work is supported by the Key Program from Chinese Academy of Science (Grant No. ZDRW-ZS-2016-6), International Partnership Program of Chinese Academy of Sciences (131C11KYSB20160061), National Natural Science Foundation of China (41371120) and Chinese Academy of Sciences-The World Academy of Sciences (CAS-TWAS) President's Fellowship Program for international Ph.D. students. We are extremely thankful to Bipin Kumar Acharya, Ramesh Raj Pant, Bhagawat Rimal and D.B. Kattel for valued idea and advice. The authors extend sincere gratitude to the editor and anonymous reviewers for their constructive comments and valuable suggestions.

Author Contributions: Yili Zhang and Raju Rai had the original idea for this review. Raju Rai had reviewed and written this manuscript. Yili Zhang, Basanta Paudel, Shicheng Li, and Narendra Raj Khanal had reviewed the manuscript and provided input in writing and finalizing the paper. All authors have read and approved the final manuscript.

Conflicts of Interest: The authors declare no conflict of interest.

\section{References}

1. Duhamel, C. Land use, Land cover, including their classification. Encylopedia Life Support Syst. 2012, 1-9.

2. Ganasri, B.; Aedla, R.; Dwarakish, G. Different Approaches for Land Use Land Cover Change Detection: A Review. Res. Rev. J. Eng. Technol. 2013, 2, 44-48.

3. Meyer, W.B.; Turner, B.I. Changes in Land Use and Land Cover: A Global Perspective; Cambridge University Press: Cambridge, UK, 1994; Volume 4.

4. Paudel, B.; Zhang, Y.-L.; Li, S.-C.; Liu, L.-S.; Wu, X.; Khanal, N.R. Review of studies on land use and land cover change in Nepal. J. Mt. Sci. 2016, 13, 643-659. [CrossRef]

5. Bringezu, S.; Schütz, H.; Pengue, W.; O’Brien, M.; Garcia, F.; Sims, R.; Howarth, R.W.; Kauppi, L.; Swilling, M.; Herrick, J. Assessing Global Land Use: Balancing Consumption with Sustainable Supply; United Nations Environment Programme: Nairobi, Kenya, 2014.

6. Lambin, E.; Turner, B.; Geist, H.; Agbola, S.; Angelsen, A.; Bruce, J.; Coomes, O.; Dirzo, R.; Fischer, G.; Folke, C.; et al. The causes of land-use and land-cover change, moving beyond the myths. Glob. Environ. Chang. 2001, 11, 261-269. [CrossRef]

7. Lepers, E.; Lambin, E.; Janetos, A.; DeFries, R.; Achard, F.; Ramankutty, N.; Scholes, R. A synthesis of information on rapid land-cover change for the period 1981-2000. BioScience 2005, 55, 115-124. [CrossRef]

8. Lambin, E.; Geist, H.; Lepers, E. Dynamics of land-use and land-cover change in tropical regions. Annu. Rev. Environ. Resour. 2003, 28, 205-241. [CrossRef]

9. Food and Agriculture Organization of the United Nations; European Commission Joint Research Centre. Global Forest Land-Use Change 1990-2005; Food and Agriculture Organization of the United Nations, European Commission Joint Research Centre: Rome, Italy, 2012.

10. Hasan, M.; Hossain, M.; Bari, M.; Islam, M. Agricultural Land Availability in Bangladesh; SRDI, Ministry of Agriculture: Dhaka, Bangladesh, 2013; p. 42. ISBN 978-984-33-6141-7.

11. Food and Agriculture Organization of the United Nations Regional Office for Asia and the Pacific. FAO Statistical Yearbook 2014; Asia and the Pacific Food and Agriculture; Food and Agriculture Organization of the United Nations Regional Office for Asia and the Pacific: Bangkok, Thailand, 2014.

12. Population Reference Bureau. 2016 World Population Data Sheet with a Special Focus on Human Needs and Sustainable Resources; Population Reference Bureau: Washington, DC, USA, 2016.

13. Hasan, S.S.; Deng, X.; Li, Z.; Chen, D. Projections of Future Land Use in Bangladesh under the Background of Baseline, Ecological Protection and Economic Development. Sustainability 2017, 9, 505. [CrossRef] 
14. D'amour, C.; Reitsma, F.; Baiocchi, G.; Barthel, S.; Güneralp, B.; Erb, K.-H.; Haberl, H.; Creutzig, F.; Seto, K.C. Future urban land expansion and implications for global croplands. Proc. Natl. Acad. Sci. USA 2016, 114, 8939-8944. [CrossRef] [PubMed]

15. Islam, M. Vegetation changes of Sundarabans based on landsat image between 1975 and 2006. Landsc. Environ. 2014, 8, 1-9.

16. Food and Agriculture Organization of the United Nations. FRA 2000; Forest Resources of Bangladesh, Country Report; Forest Department, Food and Agriculture Organization of the United Nations: Rome, Italy, 2000; p. 91.

17. Giri, C.; Shrestha, S. Land cover mapping and monitoring from NOAA AVHRR data in Bangladesh. Int. J. Remote Sens. 1996, 17, 2749-2759. [CrossRef]

18. Dewan, A.; Corner, R. Dhaka Megacity: Geospatial Perspectives on Urbanisation, Environment and Health; Springer: New York, NY, USA; London, UK, 2014.

19. Bangladesh Bureau of Statistics. Yearbook of Agricultural Statistics-2015; Bangladesh Bureau of Statistics (BBS), Statistics and Informatics Division (SID): Dhaka, Bangladesh, 2016.

20. Islam, G.M.; Islam, A.K.; Shopan, A.A.; Rahman, M.M.; Lazar, A.N.; Mukhopadhyay, A. Implications of agricultural land use change to ecosystem services in the Ganges delta. J. Environ. Manag. 2015, 161, 443-452. [CrossRef] [PubMed]

21. Malek, M.; Hossain, M.; Saha, R.; Gatzweiler, F. Mapping Marginality Hotspots and Agricultural Potentials in Bangladesh; University of Bonn: Bonn, Germany, 2013; pp. 1-30.

22. Quasem, M.A. Conversion of agricultural land to non-agricultural uses in Bangladesh: Extent and determinants. Bangladesh Dev. Stud. 2011, 34, 59-85.

23. Reddy, C.S.; Pasha, S.V.; Jha, C.S.; Diwakar, P.G.; Dadhwal, V.K. Development of national database on long-term deforestation (1930-2014) in Bangladesh. Glob. Planet. Chang. 2016, 139, 173-182. [CrossRef]

24. Rahman, S. Six decades of agricultural land use change in Bangladesh: Effects on crop diversity, productivity, food availability and the environment, 1948-2006. Singap. J. Trop. Geogr. 2010, 31, 254-269. [CrossRef]

25. Jaim, W.; Begum, R. Changes In Land Use Pattern In Bangladesh Over The Last Two Decades. Bangladesh J. Agric. Econ. 2003, 26, 87-96.

26. Dewan, A.; Yamaguchi, Y. Land use and land cover change in Greater Dhaka, Bangladesh: Using remote sensing to promote sustainable urbanization. Appl. Geogr. 2009, 29, 390-401. [CrossRef]

27. Aziz, A.; Paul, A.R. Bangladesh Sundarbans: Present status of the environment and biota. Diversity 2015, 7, 242-269. [CrossRef]

28. Alam, A.; Chowdhury, M.; Sobhan, I. Biodiversity of Tanguar Haor: A Ramsar Site of Bangladesh, Volume I: Wildlife; International Union for Conservation of Nature: Dhaka, Bangladesh, 2012; pp. 1-234.

29. Khondoker, S.; Hossain, M.L.; Moni, K.A.H. Wetland management in Bangladesh: A study on Beel Bakar. Agric. For. Fish. 2014, 3, 320-328. [CrossRef]

30. Majumder, T.; Mazumder, S.K.; Monwar, M.M.; Basak, L. Towards climate change resilient of Hail Haor, Sylhet: Reviewing the role of the co-management approach. IOSR J. Agric. Vet. Sci. 2013, 5, 59-66.

31. Uddin, K.; Gurung, D. Land cover change in Bangladesh- a knowledge based classification approach. In Proceedings of the 10th International Symposium on High Mountain Remote Sensing Cartography ICIMOD, Kathmandu, Nepal, 8-11 September 2008; pp. 41-46.

32. Turner, B.; Ali, A. Induced intensification: Agricultural change in Bangladesh with implications for Malthus and Boserup. Proc. Natl. Acad. Sci. USA 1996, 93, 14984-14991. [CrossRef] [PubMed]

33. Uddin, M.; Anwar, M.; Rahman, M.; Mobin, M. An investigation on the pattern of land use change in Dhaka city using remote sensing and GIS application. J. Environ. Sci. Nat. Resour. 2014, 7, 105-109. [CrossRef]

34. Ahmed, A.; Hussain, S.H. Changing Urban Landuse and Agricultural Land Transformation: A Case Study of Narayanganj City. ASA Univ. Rev. 2012, 6, 237-284.

35. Akther, J.; Kader, M.A.; Rahman, M.; Shawkhatuzzaman, M. Changes of land use in Fulbaria and Trishal upazila of Mymensingh district of Bangladesh. J. Bangladesh Agric. Univ. 2014, 12, 13-18. [CrossRef]

36. Mamun, A.A.; Mahmood, A.; Rahman, M. Identification and monitoring the change of land use pattern using remote sensing and GIS: A case study of Dhaka City. IOSR J. Mech. Civ. Eng. 2013, 6, 20-28. [CrossRef]

37. Sayed, M.; Haruyama, S. Dynamics of Land Use/Cover Change in Manikganj District, Bangladesh: A Case Study of Manikganj Sadar Upazila. J. Geogr. Inf. Syst. 2015, 7, 579-587. [CrossRef]

38. Sayed, M.; Haruyama, S. Urbanization Impact on Agricultural Land of Manikganj Pourashova, Bangladesh. Int. J. Sci. Basic Appl. Res. 2016, 28, 243-253. 
39. Islam, M.S.; Ahmed, R. Land use change prediction in Dhaka city using GIS aided Markov chain modeling. J. Life Earth Sci. 2011, 6, 81-89. [CrossRef]

40. Islam, M. Causes and consequences of agricultural land losses of Rajshahi District, Bangladesh. J. Environ. Sci. Toxicol. Food Technol. 2013, 5, 58-65.

41. Rahman, M.R.; Shi, Z.H.; Chongfa, C. Land use/land cover change analysis using geo-information technology: Two case studies in Bangladesh and China. Int. J. Geoinf. 2009, 5, 25-37.

42. Hassan, M.; Mahmud-ul-islam, S. Urban area change analysis in the Rangapur Sadar upazila, Bangladesh using landsat imageries. Int. J. Sci. Res. 2015, 4, 469-474.

43. Islam, W.; Sarker, S.C. Monitoring the Changing Pattern of Land Use in the Rangpur City Corporation Using Remote Sensing and GIS. J. Geogr. Inf. Syst. 2016, 8, 537-545. [CrossRef]

44. Shrestha, F.; Uddin, K.; Maharjan, S.; Bajracharya, S. Application of remote sensing and GIS in environmental monitoring in the Hindu Kush Himalayan region. AIMS Environ. Sci. 2016, 3, 646-662. [CrossRef]

45. Roy, S.; Farzana, K.; Papia, M.; Hasan, M. Monitoring and Prediction of Land Use/Land Cover Change using the Integration of Markov Chain Model and Cellular Automation in the Southeastern Tertiary Hilly Area of Bangladesh. Int. J. Sci. Basic Appl. Res. 2015, 24, 125-148.

46. Rahman, M.; Jashimuddin, M.; Islam, K.; Nath, T.K. Land Use Change and Forest Fragmentation Analysis: A Geoinformatics Approach on Chunati Wildlife Sanctuary, Bangladesh. J. Civ. Eng. Environ. Sci. 2016, 2, 020-029.

47. Islam, M.A.; Maitra, M.K.; Majlis, A.B.K.; Murshed, S.; Rahman, S. Spatial changes of land use/land cover of Moheshkhali island, Bangladesh: A fact finding approach by remote sensing analysis. Dhaka Univ. J. Earth Environ. Sci. 2011, 2, 43-54.

48. Ali, A. Population pressure, environmental constraints and agricultural change in Bangladesh: Examples from three agroecosystems. Agric. Ecosyst. Environ. 1995, 55, 95-109. [CrossRef]

49. Islam, M.; Ahmed, M.; Mamun, M.; Masunaga, S. Potential ecological risk of hazardous elements in different land-use urban soils of Bangladesh. Sci. Total Environ. 2015, 512-513, 94-102. [CrossRef] [PubMed]

50. Khan, M.M.H.; Bryceson, I.; Kolivras, K.N.; Faruque, F.; Rahman, M.M.; Haque, U. Natural disasters and land-use/land-cover change in the southwest coastal areas of Bangladesh. Reg. Environ. Chang. 2015, 15, 241-250. [CrossRef]

51. Hossain, M. Global warming induced sea level rise on soil, land and crop production loss in Bangladesh. In Proceedings 19th World Congress of Soil Science, Soil Solutions for a Changing World; Robert, G., Ed.; International Union of Soil Sciences: Crawley, UK, 2010; pp. 77-80.

52. Rahman, M.; Begum, S. Land cover change analysis around the Sundarbans Mangrove Forest of Bangladesh using remote sensing and GIS application. J. Sci. Found. 2011, 9, 95-107. [CrossRef]

53. Alam, M.S. Climate change and land use change in the Eastern Coastal Belt of Bangladesh, elucidated by analyzing rice production area in the past and future. J. Life Earth Sci. 2013, 8, 83-92. [CrossRef]

54. Jerin, T.; Ishtiaque, A. Detailing rural land use of Coastal Bangladesh: A micro-level study. Geogr. Malays. J. Soc. Space 2014, 10, 1-17.

55. Rahman, M.R.; Hossain, M.B. Changes in land use pattern at Chakaria Sundarbans mangrove forest in Bangladesh. Bangladesh Res. Publ. J. 2015, 11, 13-20.

56. Shapla, T.; Park, J.; Hongo, C.; Kuze, H. Agricultural Land Cover Change in Gazipur, Bangladesh, in Relation to Local Economy Studied Using Landsat Images. Adv. Remote Sens. 2015, 4, 214-223. [CrossRef]

57. Paul, A.; Nath, B.; Abbas, M.; Islam, H.; Mallick, B. Land use change monitoring of Hari-Teka river basin, Jessore, Bangladesh using remote sensing and GIS. Int. J. Adv. Remote Sens. GIS Geogr. 2014, 2, 1-8.

58. Raihan, F.; Kaiser, N. Land use changing scenario at Kerniganj Thana of Dhaka District using remote sensing and GIS. J. Environ. 2012, 1, 105-110.

59. Sharif, M.S.; Esa, A.J. Dynamics of land price and land use change: A case of Savar Municipality, Bangladesh. J. South Asian Stud. 2014, 2, 83-89.

60. Dewan, A.; Yamaguchi, Y. Using remote sensing and GIS to detect and monitor land use and land cover change in Dhaka Metropolitan of Bangladesh during 1960-2005. Environ. Monit. Assess. 2009, 150, 237-249. [CrossRef] [PubMed]

61. Ahmed, B.; Ahmed, R. Modeling urban land cover growth dynamics using multi-temporal satellite images: A case study of Dhaka, Bangladesh. ISPRS Int. J. Geo-Inf. 2012, 1, 3-31. [CrossRef] 
62. Pramanik, M.M.A.; Stathakis, D. Forecasting urban sprawl in Dhaka city of Bangladesh. Environ. Plan. B Plan. Des. 2016, 43, 756-771. [CrossRef]

63. Yesmin, R.; Mohiuddin, A.S.M.; Uddin, M.J.; Shahid, M.A. Land use and land cover change detection at Mirzapur Union of Gazipur District of Bangladesh using remote sensing and GIS technology. In Proceedings of the 7th IGRSM International Remote Sensing \& GIS Conference and Exhibition, Kuala Lumpur, Malaysia, 21-22 May 2014; pp. 1-9.

64. Sarker, M.; Rahman, S.; Akhand, M.; Uddin, M.; Quadir, D. Land-use changes of Kaliakair upazila of Bangladesh using Remote Sensing and GIS Technologies. Indian J. Appl. Res. 2015, 5, 532-537.

65. Haque, A.; Alam, J.; Shaha, N.; Raihan, F. Study on Land use Pattern Change and Its Causes. Int. J. Environ. Res. 2008, 2, 199-204.

66. Hassan, M.M.; Nazem, M.N.I. Examination of land use/land cover changes, urban growth dynamics, and environmental sustainability in Chittagong city, Bangladesh. Environ. Dev. Sustain. 2016, 18, 697-716. [CrossRef]

67. Hussain, M.; Alak, P.; AZMZ, I. Spatio-temporal analysis of land use and land cover changes in Chittagong city corporation, Bangladesh. Int. J. Adv. Remote Sens. GIS Geogr. 2016, 4, 56-72.

68. Sarwar, M.I.; Billa, M.; Paul, A. Urban land use change analysis using RS and GIS in Sulakbahar ward in Chittagong city, Bangladesh. Int. J. Geomat. Geosci. 2016, 7, 1-10.

69. Islam, M.; Chowdhury, S. Analysis of Changing Land Cover in Chittagong City Corporation Area (CCC) by Remote Sensing and GIS. Int. J. Innov. Appl. Stud. 2014, 8, 1193-1203.

70. Islam, M.; Hassn, M. Losses of Agricultural Land due to Infrastructural Development: A Study on Rajshahi District. Int. J. Sci. Eng. Res. 2013, 4, 391-396.

71. Islam, M. Study on impact of land fragmentation in agriculture-a case of Rajshahi district, Bangladesh. Int. J. Recent Res. Soc. Sci. Hum. 2014, 1, 54-61.

72. Kumar, L.; Ghosh, M.K. Land cover change detection of Hatiya Island, Bangladesh, using remote sensing techniques. J. Appl. Remote Sens. 2012, 6, 063608. [CrossRef]

73. Billah, M.; Rahman, G.A. Land cover mapping of Khulna city applying remote sensing technique. In Proceedings of the 12th International Conference on Geoinformatics (Sweden: Geospatial Information Research: Bridging the Pacific and Atlantic, University of Gävle), Gavle, Sweden, 7-9 June 2004; pp. 707-714.

74. Chaudhuri, G.; Mishra, N.B. Spatio-temporal dynamics of land cover and land surface temperature in Ganges-Brahmaputra delta: A comparative analysis between India and Bangladesh. Appl. Geogr. 2016, 68, 68-83. [CrossRef]

75. European Space Agency. Climate Change Initiative Land Cover (CCI-LC) Dataset 2.0 ed.; European Space Agency: Brussel, Belgium, 2017.

76. Salam, M.A.; Noguchi, T.; Koike, M. The causes of forest cover loss in the hill forests in Bangladesh. GeoJournal 1999, 47, 539-549. [CrossRef]

77. Redowan, M.; Akter, S.; Islam, N. Analysis of forest cover change at Khadimnagar National Park, Sylhet, Bangladesh, using Landsat TM and GIS data. J. For. Res. 2014, 25, 393-400. [CrossRef]

78. Iftekhar, M.S.; Hoque, A.K.F. Causes of forest encroachment: An analysis of Bangladesh. GeoJournal 2005, 62, 95-106. [CrossRef]

79. Griffiths, P.; Hostert, P.; Gruebner, O.; van der Linden, S. Mapping megacity growth with multi-sensor data. Remote Sens. Environ. 2010, 114, 426-439. [CrossRef]

80. Rahman, S.; Hasan, S.M.R.; Islam, M.A.; Maitra, M.K. Temporal change detection of vegetation coverage of Dhaka using remote sensing. Int. J. Geomat. Geosci. 2011, 2, 481-490.

81. Byomkesh, T.; Nakagoshi, N.; Dewan, A. Urbanization and green space dynamics in Greater Dhaka, Bangladesh. Landsc. Ecol. Eng. 2011, 8, 45-58. [CrossRef]

82. Jaber, A.S.; Ghosh, A.K.; Mahmud, M.S. Using Time Series of Satellite Images to Detect Vegetation Cover Change in Dhaka City. J. Geogr. Inf. Syst. 2014, 6, 653-663. [CrossRef]

83. Halim, M.A.; Shahid, A.; Chowdhury, M.S.H.; Nahar, M.N.; Sohel, M.S.I.; Nuruddin, M.J.; Koike, M. Evaluation of land-use pattern change in West Bhanugach Reserved Forest, Bangladesh, using remote sensing and GIS techniques. J. For. Res. 2008, 19, 193-198. [CrossRef]

84. Salauddin, M.; Islam, A. Identification of land cover changes of the haor area of Bangladesh using Modis Images. In Proceedings of the 3rd International Conference on Water \& Flood Management (ICWFM-2011); Institute of Water and Flood Management, BUET: Dhaka, Bangladesh, 2011. 
85. Islam, K.; Jashimuddin, M.; Nath, B.; Nath, T.K. Land use classification and change detection by using multi-temporal remotely sensed imagery: The case of Chunati wildlife sanctuary, Bangladesh. Egypt. J. Remote Sens. Space Sci. 2017, in press. [CrossRef]

86. Uddin, M.; Miah, M.; Afrad, M.; Mehraj, H.; Mandal, M. Land use change and its impact on ecosystem services, livelihood in Tanguar Haor wetland of Bangladesh. Sci. Agric. 2015, 12, 78-88.

87. Abdullah, H.M.; Mahboob, M.G.; Rahman, M.M.; Ahmed, T. Monitoring Natural Sal Forest Cover in Modhupur, Bangladesh using Temporal Landsat Imagery during 1972-2015. Int. J. Environ. 2015, 5, 1-7.

88. Sarker, S.; Kuri, K.; Chowdhury, M.; Rahman, M. Mangrove: A livelihood option for the coastal community of Bangladesh. Bangladesh Res. Publ. J. 2010, 3, 1187-1192. [CrossRef]

89. Uddin, M.S.; Shah, M.A.R.; Khanom, S.; Nesha, M.K. Climate change impacts on the Sundarbans mangrove ecosystem services and dependent livelihoods in Bangladesh. Asian J. Conserv. Biol. 2013, 2, 152-156.

90. Uddin, S.; Hoque, A.; Abdullah, S. The changing landscape of mangroves in Bangladesh compared to four other countries in tropical regions. J. For. Res. 2014, 25, 605-611. [CrossRef]

91. Rahman, M. Temporal Change detection of Vegetation Coverage in Patuakhali Coastal Area of bangladesh Using GIS \& Remotely Sensed Data. Int. J. Geomat. Geosci. 2013, 4, 36-46.

92. Halder, P.K. Impact of Coastal Flooding on Land use Pattern Considering Climate Change. In Proceedings of the Dimensions and Directions of Geospatial Industry, Hyderabad, India, 18-21 January 2011.

93. Giri, C.; Pengra, B.; Zhu, Z.; Singh, A.; Tieszen, L. Monitoring mangrove forest dynamics of the Sundarbans in Bangladesh and India using multi-temporal satellite data from 1973 to 2000. Estuar. Coast. Shelf Sci. 2007, 73, 91-100. [CrossRef]

94. Nath, B. Quantitative Assessment of Forest Cover Change of a Part of Bandarban Hill Tracts Using NDVI Techniques. J. Geosci. Geomat. 2014, 2, 21-27.

95. Mahmud, M.S.; Masrur, A.; Ishtiaque, A.; Haider, F.; Habiba, U. Remote Sensing \& GIS Based Spatio-Temporal Change Analysis of Wetland in Dhaka City, Bangladesh. J. Water Resour. Prot. 2011, 3, 781-787.

96. Sultana, M.; Islam, G.; Islam, Z. Pre-and post-urban wetland area in Dhaka City, Bangladesh: A remote sensing and GIS analysis. J. Water Resour. Prot. 2009, 2009, 414-421. [CrossRef]

97. Islam, M.; Shahabuddin, A.; Kamal, M.; Ahmed, R. Wetlands of Dhaka City: Its Past and Present Scenario. J. Life Earth Sci. 2012, 7, 83-90. [CrossRef]

98. Amin, A.K.M.K.; Haque, M.; Alamgir, M. Analysis of the Wetland Degradation around the Vicinity of Dhaka City in Bangladesh. Asian J. Water Environ. Pollut. 2013, 10, 19-26.

99. Hossain, M.W.; Feerdaus, J.; Saha, P.K.; Saifullah, A. Temporal and spatial changes of wetlands in selected areas of Dhaka city and its impact on surrounding environment. Int. J. Sci. Res. 2014, 3, 1043-1050.

100. Shopan, A.A.; Islam, A.; Dey, N.C.; Bala, S.K. Estimation of the changes of wetlands in the northwest region of Bangladesh using Landsat images. In Proceedings of the 4th International Conference on Water \& Flood Management (ICWFM-2013), Dhaka, Bangladesh, 8-10 January 2011; pp. 521-528.

101. Asia-Pacific Network for Global Change Research. Holistic Assessment of Land-Use Change and Impacts on Ecosystem Services of Wetlands; ARCP2012-05CMY-Zhen; APN (Asia-Pacific Network for Global Change Research): Kobe, Japan, 2012.

102. Roy, B.; Saha, P. Temporal Analysis of Land Use Pattern Changes in Chittagong District of Bangladesh using Google Earth and ArcGIS. In Proceedings of the Annual Int'l Conference on Chemical Processes, Ecology \& Environmental Engineering (ICCPEE'16), Pattaya, Thailand, 28-29 April 2016.

103. Islam, S.N. Deltaic floodplains development and wetland ecosystems management in the GangesBrahmaputra-Meghna Rivers Delta in Bangladesh. Sustain. Water Resour. Manag. 2016, 2, 237-256. [CrossRef]

104. Food and Agriculture Organization of the United Nations FAO. Bangladesh Food Security Brief; World Food Programme, Vulnerability Analysis and Mapping Unit WFP: Dhaka, Bangladesh, 2005.

105. Begum, M.; D'Haese, L. Supply and demand situations for major crops and food items in Bangladesh. J. Bangladesh Agric. Univ. 2010, 8, 91-102. [CrossRef]

106. Dobermann, A.; Nelson, R.; Beever, D.; Bergvinson, D.; Crowley, E.; Denning, G.; Giller, K.; d'Arros Hughes, J.; Jahn, M.; Lynam, J. Solutions for Sustainable Agriculture and Food Systems; Technical Report for the Post-2015 Development Agenda; Sustainable Development Solutions Network (SDSN): New York, NY, USA, 2013; pp. 1-108. 
107. Magnani, R.; Oot, L.; Sethuraman, K.; Kabir, G.; Rahman, S. USAID Office of Food for Peace Food Security Country Framework for Bangladesh (FY 2015-2019); Food and Nutrition Technical Assistance III Project: Washington, DC, USA, 2015; pp. 1-69.

108. Ali, A. Farmers' knowledge of soils and the sustainability of agriculture in a saline water ecosystem in Southwestern Bangladesh. Geoderma 2003, 111, 333-353. [CrossRef]

109. Ali, A. Technological change in agriculture and land degradation in Bangladesh: A case study. Land Degrad. Dev. 2004, 15, 283-298. [CrossRef]

110. Ali, A. Rice to shrimp: Land use/land cover changes and soil degradation in Southwestern Bangladesh. Land Use Policy 2006, 23, 421-435. [CrossRef]

111. Mondal, G. Effects of land use changes on livelihood pattern of small farmers. BRAC Univ. J. 2008, 2, 93-99.

112. Food Planning and Monitoring Unit. National Food Policy Plan of Action (2008-2015); Food Planning and Monitoring Unit (FPMU), Ministry of Food and Disaster Management: Dhaka, Bangladesh, 2008; p. 103.

113. Food and Agriculture Organization of the United Nations FAO. Bangladesh Food Security Brief; World Food Programme, Vulnerability Analysis and Mapping Unit WFP: Dhaka, Bangladesh, 2002.

114. Kashem, M.; Faroque, M. A Country Scenarioes of Food Security and Governance in Bangladesh. J. Sci. Found. 2011, 9, 41-50. [CrossRef]

115. IFAD. Investing in Rural People in Bangladesh; International Fund for Agricultural Development: Rome, Italy, 2015; pp. 1-4.

116. Karim, Z.; Bakar, M.; Islam, M. Study of the Implementation Status and Effectiveness of New Agricultural Extension Policy for Technology Adoption; National Food Policy Capacity Strengthening Programme (NFPCSP): Dhaka, Bangladesh, 2009.

117. Technical Assistance to NGO's (TANGO); World Food Programme (WFP). Rural Bangladesh, Socio-Economic Profiles of WFP Operational Areas and Beneficiaries; United Nations World Food Programme: Dhaka, Bangladesh, 2006; pp. 1-190.

118. Bhuyan, S.; Islam, S. Present Status of Socio-economic Conditions of the Fishing Community of the Meghna River Adjacent to Narsingdi District, Bangladesh. J. Fish. Livest. Product. 2016, 04, 1-5.

119. Rimal, B.; Zhang, L.; Keshtkar, H.; Wang, N.; Lin, Y. Monitoring and Modeling of Spatiotemporal Urban Expansion and Land-Use/Land-Cover Change Using Integrated Markov Chain Cellular Automata Model. ISPRS Int. J. Geo-Inf. 2017, 6, 288. [CrossRef]

120. Bangladesh Bureau of Statisties. Population and Housing Census-2011; Bangladesh Bureau of Statisties (BBS), Ministry of Planning, Statistics and Informatics Division (SID): Dhaka, Bangladesh, 2014; pp. 1-640.

121. Food and Agriculture Organization of the United Nations FAO. Global Forest Resources Assessemnt 2010 Country Reports, Bangladesh; Forestry Department, Food and Agriculture Organization of the United Nations: Rome, Italy, 2010.

122. Ali, M.; Islam, M.; Siddiqee, R.; Islam, M. Global Forest Resources Assessment 2015, Country Report, Bangladesh; Global Forest Resources Assessment 2015 (FRA 2015): Rome, Italy, 2014; p. 107.

123. Ahmed, A.M.M.M.; Roy, K. Utilization and Conservation of Water Resources in Bangladesh. J. Dev. Sustain. Agric. 2007, 2, 35-44.

124. Bangladesh Bureau of Statistics BBS. Statistical Pocketbook Bangladesh, 2015; Bangladesh Bureau of Statistics, Statistics and Information (SID): Dhaka, Bangladesh, 2016.

125. Anderson, J.; Hardy, E.; Roach, J.; Witmer, R. A Land Use and Land Cover Classification System for Use with Remote Sensor Data; US Government Printing Office: Washington, DC, USA, 1976; pp. 1-28.

126. Mohajan, H. Food, Agriculture and Economic Situation of Bangladesh. In Proceedings of the 2nd International Conference on Global Sustainable Development (2nd ICGSD-2013), Karachi, Sindh, Pakistan, 5-6 October 2013.

127. Hossain, M. Improving Land Administration and Management in Bangladesh; General Economics Division of the Planning Commision, Bangladesh Institute of Development studies (BIDS): Dhaka, Bangladesh, 2015; pp. 1-41.

(C) 2017 by the authors. Licensee MDPI, Basel, Switzerland. This article is an open access article distributed under the terms and conditions of the Creative Commons Attribution (CC BY) license (http://creativecommons.org/licenses/by/4.0/). 